\title{
Demodex Mite, Rosacea and Skin Melanoma; Coincidence or Association?
}

\author{
Demodeks Akarı, Rozasea ve Deri Melanomu; Rastlantısal veya İlişkili Birliktelik?
}

\section{Shahla Talghini', Daniel F Fouladi', Shahla Babaeinejad², Reihan Shenasi', Simin Mirakhor Samani}

1Department of Pathology, Tabriz University of Medical Sciences, Tabriz, Iran

${ }^{2}$ Department of Dermatology, Tabriz University of Medical Sciences, Tabriz, Iran

${ }^{3}$ Department of Pathology, Qazvin University of Medical Sciences, Qazvin, Iran,

\section{ABSTRACT}

Objective: To examine the possible associations between Demodex folliculorum and a number of skin diseases.

Methods: Standardized skin surface biopsy samples were obtained from the cheeks of 144 patients with histopathologically proven basal cell carcinoma ( $B C C, n=27)$, squamous cell carcinoma ( $S C C, n=28)$, melanoma ( $n=23)$, discoid lupus erythematosus ( $D L E, n=32)$, and rosacea $(n=34)$. Thirty-four sex- and age-matched healthy volunteers served as controls. Mite density (per $\left.\mathrm{cm}^{2}\right)$ and infestation $($ density $\geq 5)$ were compared between the controls and patients.

Results: Mite infestation rates (\%) did not differ significantly between the controls (20.6) and patients with BCC (22.2, $\mathrm{p}=0.88)$, SCC (17.9, $p=0.79)$, melanoma (4.3, $p=0.08)$, and $\operatorname{DLE}(21.9, p=0.90)$. Compared with the controls, the mite infestation rate was significantly higher in patients with rosacea (47.1, $p=0.02$, odds ratio: $3.43,95 \%$ confidence interval: 1.18-9.99). The mean mite density did not differ significantly between the controls $(4.11 \pm 2.17)$ and patients with BCC $(5.34 \pm 2.35, p=0.75), S C C(3.57 \pm 2.01, p=0.38)$, and DLE $(3.56 \pm 1.34, p=0.83)$, whereas it was significantly higher in patients with rosacea $(8.78 \pm 3.58, p=0.02)$ and lower in patients with melanoma $(1.89 \pm 0.69, p=0.02)$.

Conclusions: $D$. folliculorum may be associated with rosacea and melanoma but not with BCC, SCC, or DLE. (Turkiye Parazitol Derg 2015; 39: 41-6)

Keywords: Basal cell carcinoma, Demodex, discoid lupus erythematosus, melanoma, rosacea, squamous cell carcinoma

Received: 12 Aralık 2014

Accepted: 20 Kasım 2014

\section{ÖZET}

Amaç: Demodex folliculorum ve bir dizi deri hastalıkları arasındaki muhtemel bağlantıyı incelemek.

Metot: Standardize yüzeyel deri biyopsisi örnekleri; bazal hücreli karsinom (BCC, n=27), skuamöz hücreli karsinom (SCC, $n=28)$, melanom $(n=23)$, diskoid lupus eritematozus ( $D L E, n=32)$, ve rozasea $(n=34)$ tanıları histopatolojik olarak kanıtlanmış 144 hastanın yanaklarından alındı. Cinsiyet ve yaşı eşleştirilmiş 34 sağlıklı gönüllü kontrol grubunu oluşturdu. Akar dansitesi ( $\mathrm{cm}^{2}$ başına) ve enfestasyon (dansite $\geq 5$ ) hasta ve kontrol grubu arasında karşılaştırıldı.

Bulgular: Akar enfestasyon hızları (\%) kontrol grubu $(20,6)$ ile BCC $(22,2, p=0,88), \operatorname{SCC}(17,9, p=0,79)$, melanom $(4,3, p=0,08)$, ve DLE $(21,9$, $\mathrm{p}=0,90)$ hastaları arasında anlamlı bir farklılık göstermedi. Kontrol grubuna kıyasla, akar enfestasyon hızı, rozasea olanlarda anlamlı olarak yüksekti (47,1, p=0,02; odds oranı: 3,43, \%95 güven aralığı: 1,18-9,99). Ortalama akar dansitesi kontrol grubu $(4,11 \pm 2,17)$ ile BCC $(5,34 \pm 2,35$, $p=0,75), \operatorname{SCC}(3,57 \pm 2,01, p=0,38)$, ve DLE $(3,56 \pm 1,34, p=0,83)$ hasta grupları arasında anlamlı bir fark göstermezken, kontrol grubuna kıyasla

Address for Correspondence / Yazışma Adresi: Dr. Simin Mirakhor Samani, Department of Pathology, Qazvin University of Medical Sciences, Qazvin, Iran. Phone: +989121824551 E-mail: samanilab@yahoo.com

DOI: 10.5152/tpd.2015.3473

OTelif hakkı 2015 Türkiye Parazitoloji Derneği - Makale metnine www.tparazitolderg.org web sayfasından ulaşılabilir.

(C) Copyright 2015 Turkish Society for Parasitology - Available online at www.tparazitolderg.org 
rozasea hastalarında $(8,78 \pm 3,58, p=0,02)$ anlamlı olarak daha yüksekti ve melanom hastalarında $(1,89 \pm 0,69$, $p=0,02)$ anlamlı olarak daha düşüktü.

Sonuç: Demodex folliculorum, rozasea ve melanom ile ilişkili olabilir, ancak BCC, SCC ve DLE ile ilişkilendirilemez. (Turkiye Parazitol Derg 2015; 39: 41-6)

Anahtar Sözcükler: Bazal hücreli karsinom, Demodex, diskoid lupus eritematozus, melanom, rozasea, skuamöz hücreli karsinom

Geliş Tarihi: 12 Aralık 2013

Kabul Tarihi: 20 Kasım 2014

\section{INTRODUCTION}

The human hair follicle mites Demodex folliculorum and D. brevis are obligatory commensals of the pilosebaceous unit and the most prevalent ectoparasites (1)

Despite their high existence rates, these mites usually do not cause symptoms unless their density is abnormally increased on the skin (i.e., $>5$ mites per $\mathrm{cm}^{2}$ ) (2). More importantly, some studies have proposed causative/exacerbating roles for Demodex mites in the pathogenesis of several benign and malignant skin diseases such as rosacea (3), pityriasis (4), skin bacterial infections (5), dermatitis (6) acne vulgaris (7), basal cell carcinoma $(\mathrm{BCC})$, and squamous cell carcinoma (SCC) $(8,9)$.

Although the exact underlying mechanisms of such associations between particular skin diseases and Demodex mites are yet to be elucidated, several hypotheses have been suggested: (i) provocation of inflammatory and immune reactions, (ii) role of Demodex mites as a vector for other pathogens, and (iii) mechanical obstruction of the follicles (10)

Because of these uncertainties and considering the clinical and therapeutic implications of a probable association between Demodex mites and some skin diseases, further investigations are necessary. Well-designed, case-controlled studies, in particular, are essential to rule out a possibility of a mere coincidence of skin diseases and Demodex infestation (11).

Thus, the present study sought to examine a possible association of $D$. folliculorum density and its infestation rate with some malignant (i.e., BCC, SCC, and melanoma) and non-malignant [i.e., discoid lupus erythematosus (DLE) and rosacea] skin diseases.

\section{METHODS}

\section{Study population}

After approval by the ethics committee of the Tabriz University of Medical Sciences, a total of 144 patients with histopathologically proven BCC $(n=27), \operatorname{SCC}(n=28)$, melanoma $(n=23), D L E$ $(n=32)$, and inflammatory (papulopustular) rosacea $(n=34)$ were recruited from 3 dermatopathology teaching centers from October 2008 through July 2014.

The principal lesions in patients with BCC, SCC, and melanoma were located on the cheeks. In patients with DLE and rosacea, the cheeks were clinically involved.

A series of healthy age- and sex-matched volunteers $(n=34)$ with no dermatological disease or telangiectasia served as controls.

Patients with a history of receiving any topical and/or systemic antibiotic, acaricides, and corticosteroid/immunosuppressive within a month prior to enrolment and those who underwent radiotherapy and/or chemotherapy before skin samplings were not included.

Informed written consents were obtained from all participants.

\section{Procedure}

The presence of $D$. folliculorum was investigated by a non-invasive technique, known as standardized skin surface biopsy (SSSB). For this, a drop of cyanoacrylate glue (approximately 0.05 $\mathrm{mL}$ ) was placed on a $1-\mathrm{cm}^{2}$ area marked on a slide glass surface by a waterproof pen.

The adhesive-containing side was pressed against the cheek skin for approximately $1 \mathrm{~min}$ and then peeled off gently. Cover slips were placed on the sample covered by 2 drops of immersion oil; the specimens thus prepared were examined immediately under light microscopy ( $\times 40$ and $\times 100$ magnification) by a skilled dermatopathologist (with over 10 years of experience) blind to the groupings.

In the groups including patients with BCC, SCC, and melanoma, the samplings were performed from the skin adjacent to the lesions and the symmetrical spots of the contralateral (uninvolved) cheek.

In the groups including patients with DLE and rosacea, the samplings were performed from both cheeks. In order to perform between-group comparisons, the results acquired from the right cheeks were arbitrarily employed.

The skin and the slides were cleansed with ether prior to the samplings (12).

Cheek Demodex density was reported as the number of mites per $\mathrm{cm}^{2}$ of the skin $(6,13)$. Infestation was considered positive when the mite density was $\geq 5$ per $\mathrm{cm}^{2}$ (14).

\section{Statistical analysis}

SPSS software version 16.0 (SPSS Inc., IL, USA) was used for statistical analysis. One-way analysis of variance (ANOVA), Tukey's post-hoc test, independent samples $t$ test, and chi-square test were used for comparisons where appropriate. A p-value of $\leq 0.05$ was considered statistically significant.

\section{RESULTS}

The demographic information of the study groups, including sex and age, is presented in Table 1.

No significant differences were present between the groups of patients and healthy controls in terms of sex and age $(p>0.05$ for all comparisons).

Cheek mite infestation was positive in 7 healthy controls (20.6\%), 6 patients with BCC (22.2\%), 5 patients with SCC (17.9\%), 1 patient with melanoma (4.3\%), 7 patients with DLE $(21.9 \%)$, and 16 patients with rosacea (47.1\%) (Figure 1).

In comparison with the controls, no significant differences were found in terms of cheek mite infestation rates in the BCC $[p=0.88$, odds ratio $(O R)=1.10,95 \%$ confidence interval $(\mathrm{Cl})$ : 0.323.77], SCC $(p=0.79, O R=0.84,95 \% \mathrm{Cl}: 0.22-3.00)$, melanoma 
Table 1. Demographic information of the study groups

\begin{tabular}{|c|c|c|c|c|c|}
\hline \multirow[b]{2}{*}{ Study groups (n) } & \multirow[b]{2}{*}{ Age (year) } & \multicolumn{2}{|c|}{ Sex } & \multirow[b]{2}{*}{ p-value ${ }^{a}$} & \multirow[b]{2}{*}{ p-value } \\
\hline & & Male & Female & & \\
\hline Basal cell carcinoma (27) & $65.21 \pm 13.12$ & $16(59.3)$ & $11(40.7)$ & 0.69 & 0.62 \\
\hline Squamous cell carcinoma (28) & $64.09 \pm 13.22$ & $19(67.9)$ & $9(32.1)$ & 0.59 & 0.23 \\
\hline Melanoma (23) & $66.38 \pm 12.59$ & $12(52.2)$ & $11(47.8)$ & 0.13 & 0.96 \\
\hline Discoid lupus erythematosus (32) & $61.44 \pm 18.14$ & $16(50)$ & $16(50)$ & 0.27 & 0.81 \\
\hline Rosacea (34) & $60.09 \pm 20.20$ & $16(47.1)$ & $18(52.9)$ & 0.52 & 0.63 \\
\hline Control (34) & $64.24 \pm 19.45$ & $18(52.9)$ & $16(47.1)$ & - & - \\
\hline \multicolumn{6}{|c|}{$\begin{array}{l}\text { Data are presented as mean } \pm \text { standard deviation or frequency (\%). } \\
\text { a Age of patients vs. age of controls } \\
\text { bSex of patients vs. sex of controls } \\
{ }^{*} p \leq 0.05 \text { is considered statistically significant. }\end{array}$} \\
\hline
\end{tabular}

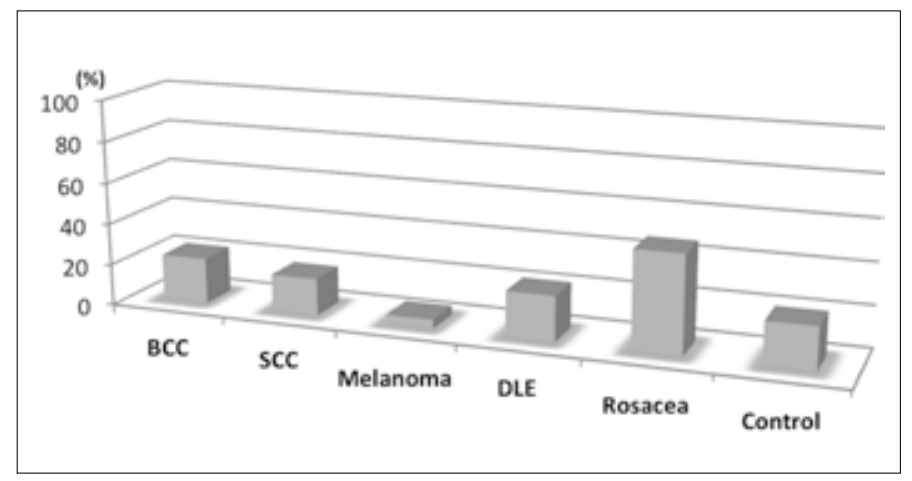

Figure 1. Cheek mite infestation rates in the study groups BCC: basal cell carcinoma, DLE: discoid lupus erythematosus, SCC: squamous cell carcinoma

( $p=0.08, O R=0.18,95 \% \mathrm{Cl}: 0.02-1.54)$, or $\mathrm{DLE}(\mathrm{p}=0.90, \mathrm{OR}=1.10$, 95\% Cl: 0.33-3.52) groups.

The rate of cheek mite infestation, however, was significantly higher in the rosacea group compared with the controls $(p=0.02$, $\mathrm{OR}=3.43,95 \% \mathrm{Cl}: 1.18-9.99$ ).

The mean cheek mite densities in the study groups are summarized in Table 2.

No significant differences were documented when the 2 sides in each group were compared with each other.

Statistically significant differences were found between the study groups concerning the mean cheek mite densities on the involved (for the BCC, SCC, and melanoma groups) or right (for the DLE, rosacea, and control groups) sides ( $p=0.03$ ).

According to the results of post-hoc analysis, statistically significant differences were present between the control and melanoma groups ( $p=0.02$ ) as well as between the control and rosacea groups $(p=0.02)$.

\section{DISCUSSION}

We found that both mite density and infestation rate were associated with rosacea in the present study. This finding is in line with that of previous reports (15-21).
It has been postulated that increased mite number in cases with abnormally elevated mite density may lead to the obstruction of the hair follicles and plugging of the sebaceous ducts. In addition, presence of mites on the skin may damage the follicular epithelia directly or indirectly through the induction of hypersensitivity reactions. Co-infections with Staphylococcus albus and Bacillus oleronius are frequently seen in patients with rosacea, and Demodex mite infestation has raised a concern regarding the role of these mites as a vector for the bacteria. The exact mechanism underlying the connection between rosacea and Demodex mites, however, is not identified (22-24).

It should be noted that the patients with rosacea examined in the present study were affected only with the papulopustular subtype of the disease. In a previous study, however, it was concluded that a probable pathological role of Demodex mites in rosacea is independent of the disease subtype (25).

In another part of this study, we did not find a significant association of mite density or infestation rate with DLE. Similar findings were reported in another study by Perrigouard et al. (26) who detected no mites on the skin of patients with lupus erythematosus. In another series, Moravvej et al. (27) reported Demodex spp. on the skin of $38.6 \%$ of patients with rosacea and only $21.3 \%$ of patients with DLE. Both reported values are close to those found in the present study. In conformity with our results, Roihu et al. (28) also reported no significant difference in mite counts of infested follicles between patients with DLE and healthy referents.

Unlike benign skin disorders such as rosacea and DLE, available data in the literature concerning the association between Demodex mites and malignant skin conditions are conflicting. In a study on Turkish patients, Erbagci et al. (9) reported a higher infestation rate and mean density of Demodex mites in patients with BCC compared with that in a healthy sex- and age-matched group. In another series by Sun et al. (8), facial skin specimens were obtained from patients with BCC and SCC and non-malignant skin disease. They found that the rate of mite infestation was significantly higher in patients with BCC and lower in patients with SCC compared with that in patients with non-malignant conditions. In contrast to these studies, we did not observe significant associations between SCC/BCC and D. follic- 
Table 2. Cheek mite densities in the study groups

\begin{tabular}{|c|c|c|c|c|}
\hline Study groups (n) & Side & Mite density (per $\mathrm{cm}^{2}$ ) & $p$-value ${ }^{a}$ & $p$-value ${ }^{b}$ \\
\hline \multirow[t]{2}{*}{ Basal cell carcinoma (27) } & Affected & $5.34 \pm 2.35$ & \multirow[t]{2}{*}{0.75} & \multirow[t]{2}{*}{0.89} \\
\hline & Unaffected & $5.01 \pm 2.12$ & & \\
\hline \multirow[t]{2}{*}{ Squamous cell carcinoma (28) } & Affected & $3.57 \pm 2.01$ & \multirow[t]{2}{*}{0.38} & \multirow[t]{2}{*}{0.79} \\
\hline & Unaffected & $4.56 \pm 2.36$ & & \\
\hline \multirow[t]{2}{*}{ Melanoma (23) } & Affected & $1.89 \pm 0.69$ & \multirow[t]{2}{*}{$0.02^{\star}$} & \multirow[t]{2}{*}{0.63} \\
\hline & Unaffected & $1.17 \pm 0.35$ & & \\
\hline \multirow[t]{2}{*}{ Discoid lupus erythematosus (32) } & Right & $3.56 \pm 1.34$ & \multirow[t]{2}{*}{0.83} & \multirow[t]{2}{*}{0.83} \\
\hline & Left & $3.90 \pm 1.29$ & & \\
\hline \multirow[t]{2}{*}{ Rosacea (34) } & Right & $8.78 \pm 3.58$ & \multirow[t]{2}{*}{$0.02^{*}$} & \multirow[t]{2}{*}{0.91} \\
\hline & Left & $8.18 \pm 3.12$ & & \\
\hline \multirow[t]{2}{*}{ Control (34) } & Right & $4.11 \pm 2.17$ & \multirow[t]{2}{*}{-} & \multirow[t]{2}{*}{0.92} \\
\hline & Left & $4.01 \pm 2.23$ & & \\
\hline \multicolumn{5}{|c|}{$\begin{array}{l}\text { Data are presented as mean } \pm \text { standard error of the mean } \\
\text { aPatients vs. controls } \\
\text { bAffected side vs. unaffected side or right side vs. left side } \\
{ }^{*} \mathrm{p} \leq 0.05 \text { is considered statistically significant. }\end{array}$} \\
\hline
\end{tabular}

ulorum. This heterogeneity between reports may arise from methodological flaws and varying characteristics of the study populations. Missing well-selected control groups; different time, sites, and methods of sampling; and employment of inappropriate techniques for detecting mites and calculating their density are possible confounding factors.

Some studies have suggested a direct, significant correlation between the likelihood of mite infestation and age $(29,30)$. All our patient groups were comparable with the controls in terms of age.

Although no significant associations have been shown between mite infestation and host gender, skin type, hygiene, and use of cosmetics (31) we did our best to select patients and healthy referents with the highest similarities for these factors.

Because an incompetent immune system has been suggested as a potential risk factor for pathological mite infestations $(32,33)$, we performed all samplings prior to the commencement of any treatment to ensure that the patients' immune system was unaffected. In addition, all samplings in the present study were performed on the cheek skin, because the highest density of mites has been reported to be on this facial area (34).

There are various skin sampling methods in order to examine Demodex mites. Using adhesive tapes, comedo extraction, hair epilation, skin impression/scraping, skin biopsy, and skin surface biopsy are the most commonly used techniques in this regard $(13,14,34)$. We chose the SSSB technique owing to its non-invasiveness and high sensitivity compared with the other available methods $(12,35)$.

Although statistically insignificant, the rate of mite infestation was clearly lower in specimens obtained from patients with melanoma in comparison with those obtained from the controls
(4.3\% vs. 20.6\%; $p=0.08$ ). Significantly lower mean mite density in patients with melanoma compared with that in the controls further corroborated a possible association between $D$. folliculorum and melanoma. To the best of our knowledge, this is the first study in the literature that reports such an association. Although the results need to be clarified in future studies, this finding may suggest a shared point in human immunological host defense against both melanoma and Demodex mites (36-38). Although challenging in its essence, another relevant hypothesis may be a protective role of mites against melanoma or vice versa.

In the present study, no significant differences were found between the 2 cheeks in each group in terms of mite infestation rates, a finding in line with that of a previous report indicating symmetrical facial mite distribution in healthy individuals (35). It is not known whether this symmetry represents a systemic rather than local phenomenon in connecting skin disease and Demodex mites.

\section{CONCLUSION}

According to the findings of the present study, there may be no association between D. folliculorum and BCC, SCC, and DLE. In conformity with available data, both Demodex mite density and infestation rate could be associated with rosacea. An inverse association was observed between $D$. folliculorum and melanoma, which merits investigation in future, multi-center studies.

Ethics Committee Approval: Ethics committee approval was received for this study from the ethics committee of Tabriz University of Medical Sciences.

Informed Consent: Written informed consent was obtained from patients who participated in this study.

Peer-review: Externally peer-reviewed. 
Author Contributions: Consept - S.T.; Design - S.T., D.F.F., S.B., R.S., S.M.S.; Supervision - S.T.; Funding - S.T., S.M.S.; Materials S.T., D.F.F., S.B., R.S., S.M.S.; Data Collection and/or Processing - S.T., D.F.F., S.B., R.S., S.M.S.; Analysis and/or Interpretation S.T., D.F.F., S.B., R.S., S.M.S.; Literature Review - D.F.F.; Writer D.F.F.; Critical Review - S.T., D.F.F., S.B., R.S., S.M.S.

Conflict of Interest: No conflict of interest was declared by the authors.

Financial Disclosure: This study was financially supported by Shahla Talghini and Simin Mirakhor Samani.

Etik Komite Onayı: Bu çalışma için etik komite onayı Tabriz Üniversitesi Medikal Bilimler'den alınmıştır.

Hasta onamı: Yazılı hasta onamı bu çalışmaya katılan hastalardan alınmıştır.

Hakem Değerlendirmesi: Dış Bağımsız.

Yazar Katkıları: Fikir - S.T.; Tasarım - S.T., D.F.F., S.B., R.S., S.M.S.; Denetleme - S.T.; Kaynaklar - S.T., S.M.S.; Malzemeler - S.T., D.F.F., S.B., R.S., S.M.S.; Veri Toplanması ve/veya işlemesi - S.T., D.F.F., S.B., R.S., S.M.S.; Analiz ve/veya Yorum - S.T., D.F.F., S.B., R.S., S.M.S.; Literatür taraması - D.F.F.; Yazıyı Yazan - D.F.F.; Eleştirel Inceleme - S.T., D.F.F., S.B., R.S., S.M.S.

Çıkar Çatışması: Yazarlar çıkar çatışması bildirmemişlerdir.

Finansal Destek: Bu çalışma, Shahla Talghini ve Simin Mirakhor Samani tarafından desteklenmiştir.

\section{REFERENCES}

1. Lacey N, Kavanagh K, Tseng SC. Under the lash: Demodex mites in human diseases Biochem (Lond) 2009; 31: 2-6.

2. Dhingra KK, Saroha V, Gupta P, Khurana N. Demodex-associated dermatologic conditions--A coincidence or an etiological correlate. Review with a report of a rare case of sebaceous adenoma. Pathol Res Pract 2009; 205: 423-6. [CrossRef]

3. Hsu CK, Hsu MM, Lee JY. Demodicosis: a clinicopathological study. J Am Acad Dermatol 2009; 60: 453-62. [CrossRef]

4. Baima B, Sticherling M. Demodicidosis revisited. Acta Derm Venereol 2002; 82: 3-6. [CrossRef]

5. Ozdemir MH, Aksoy U, Sonmez E, Akisu C, Yorulmaz C, Hilal A. Prevalence of Demodex in health personnel working in the autopsy room. Am J Forensic Med Pathol 2005; 26: 18-23. [CrossRef]

6. Karincaoglu Y, Tepe B, Kalayci B, Atambay M, Seyhan M. Is Demodex folliculorum an aetiological factor in seborrhoeic dermatitis? Clin Exp Dermatol 2009; 34: e516-20. [CrossRef]

7. Karaman U, Celik T, Calik S, Sener S, Aydin NE, Daldal UN. Demodex spp. in hairy skin biopsy specimens. Turkiye Parazitol Derg 2008; 32: 343-5.

8. Sun J, Gui X, He J, Liu HM, Yu HY, Xia CY, et al. The relationship between infestation of Demodex folliculorum and epidermal neoplasm on face. Zhongguo Ji Sheng Chong Xue Yu Ji Sheng Chong Bing Za Zhi 2005; 23: 428-31.

9. Erbagci Z, Erkilic, S. Basal cell carcinoma and demodicidosis: Is there an etiologic or coincidental relationship? Turkish Journal of Cancer 2000; 30: 111-8.

10. Powell FC. Rosacea and the pilosebaceous follicle. Cutis 2004; 74 (3 Suppl): 32-4.

11. Elston DM. Demodex mites: facts and controversies. Clin Dermatol 2010; 28: 502-4. [CrossRef]
12. Forton F, Song M. Limitations of standardized skin surface biopsy in measurement of the density of Demodex folliculorum. A case report. Br J Dermatol 1998; 139: 697-700. [CrossRef]

13. Erbagci Z, Ozgoztasi O. The significance of Demodex folliculorum density in rosacea. Int J Dermatol 1998; 37: 421-5. [CrossRef]

14. Forton F, Seys B. Density of Demodex folliculorum in rosacea: a case-control study using standardized skin-surface biopsy. $\mathrm{Br} \mathrm{J}$ Dermatol 1993; 128: 650-9. [CrossRef]

15. el-Shazly AM, Ghaneum BM, Morsy TA, Aaty HE. The pathogenesis of Demodex folliculorum (hair follicular mites) in females with and without rosacea. J Egypt Soc Parasitol 2001; 31: 867-75.

16. Abd-El-Al AM, Bayoumy AM, Abou Salem EA. A study on Demodex folliculorum in rosacea. J Egypt Soc Parasitol 1997; 27: 183-95.

17. Jarmuda S, O'Reilly N, Zaba R, Jakubowicz O, Szkaradkiewicz A, Kavanagh K. Potential role of Demodex mites and bacteria in the induction of rosacea. J Med Microbiol 2012; 61 (Pt 11): 1504-10. [CrossRef]

18. Parodi A, Drago F, Paolino S, Cozzani E, Gallo R. Treatment of rosacea. Ann Dermatol Venereol 2011; 138 (Suppl 3): 211-4. [CrossRef]

19. Lazaridou E, Giannopoulou C, Fotiadou C, Vakirlis E, Trigoni A, loannides $\mathrm{D}$. The potential role of microorganisms in the development of rosacea. J Dtsch Dermatol Ges 2011; 9: 21-5. [CrossRef]

20. Zhao $Y E, W u L P$, Peng $Y$, Cheng $H$. Retrospective analysis of the association between Demodex infestation and rosacea. Arch Dermatol 2010; 146: 896-902.

21. Sattler EC, Maier T, Hoffmann VS, Hegyi J, Ruzicka T, Berking C. Noninvasive in vivo detection and quantification of Demodex mites by confocal laser scanning microscopy. Br J Dermatol 2012; 167: 1042-7. [CrossRef]

22. Rios-Yuil JM, Mercadillo-Perez P. Evaluation of Demodex folliculorum as a Risk Factor for the Diagnosis of Rosacea In Skin Biopsies. Mexico's General Hospital (1975-2010). Indian J Dermatol 2013; 58 : 157. [CrossRef]

23. Crawford GH, Pelle MT, James WD. Rosacea: I. Etiology, pathogenesis, and subtype classification. J Am Acad Dermatol 2004; 51: 327-41. [CrossRef]

24. Yamasaki K, Gallo RL. The molecular pathology of rosacea. J Dermatol Sci 2009; 55: 77-81. [CrossRef]

25. Casas C, Paul C, Lahfa M, Livideanu B, Lejeune O, Alvarez-Georges $S$, et al. Quantification of Demodex folliculorum by PCR in rosacea and its relationship to skin innate immune activation. Exp Dermatol 2012; 21: 906-10. [CrossRef]

26. Perrigouard C, Peltre B, Cribier B. A histological and immunohistological study of vascular and inflammatory changes in rosacea. Ann Dermatol Venereol 2013; 140: 21-9. [CrossRef]

27. Moravvej H, Dehghan-Mangabadi M, Abbasian MR, MeshkatRazavi G. Association of rosacea with demodicosis. Arch Iran Med 2007; 10: 199-203

28. Roihu T, Kariniemi AL. Demodex mites in acne rosacea. J Cutan Pathol 1998; 25: 550-2. [CrossRef]

29. Erbagci Z, Erbagci I, Erkilic S. High incidence of demodicidosis in eyelid basal cell carcinomas. Int J Dermatol 2003; 42: 567-71. [CrossRef]

30. Aycan OM, Otlu GH, Karaman U, Daldal N, Atambay M. Frequency of the appearance of Demodex sp. in various patient and age groups. Turkiye Parazitol Derg 2007; 31: 115-8.

31. Andrews JR. The prevalence of hair follicle mites in caucasian New Zealanders. N Z Med J 1982; 95: 451-3.

32. Akilov OE, Mumcuoglu KY. Association between human demodicosis and HLA class I. Clin Exp Dermatol 2003; 28: 70-3. [CrossRef]

33. Akilov OE, Mumcuoglu KY. Immune response in demodicosis. J Eur Acad Dermatol Venereol 2004; 18: 440-4. [CrossRef]

34. Bonnar E, Eustace P, Powell FC. The Demodex mite population in rosacea. J Am Acad Dermatol 1993; 28: 443-8. [CrossRef] 
35. Kligman AM, Christensen MS. Demodex folliculorum: requirements for understanding its role in human skin disease. J Invest Dermatol 2011; 131: 8-10. [CrossRef]

36. Tsutsumi Y. Deposition of IgD, alpha-1-antitrypsin and alpha-1-antichymotrypsin on Demodex folliculorum and D. brevis infesting the pilosebaceous unit. Pathol Int 2004; 54: 32-4. [CrossRef]
37. Strohal R, MarbergerK, Pehamberger H, Stingl G. Immunohistological analysis of anti-melanoma host responses. Arch Dermatol Res 1994; 287: 28-35. [CrossRef]

38. thor Straten P, Becker JC, Guldberg P, Zeuthen J. In situ T cells in melanoma. Cancer Immunol Immunother 1999; 48: 386-95. [CrossRef] 